\title{
Transforming a Traditional Forage/Livestock System to Improve Human Nutrition in Tropi- cal Africa
}

\author{
G.M. SULlIVAN, K.W. STOKES, D.E. FARRIS, T.C. NELSEN, AND T.C. CARTWRIGHT
}

\section{Abstract}

Livestock systems based on uncontrolled communal grazing result in inefficient utilization of native forages and low livestock production. Forage/livestock herd simulation models are adapted to Tanzania to evaluate a case of improved technology. A hay enterprise for lactating cows, not possible with uncontrolled communal grazing, was found to increase nutritional and monetary welfare of a typical village.

Major livestock production in Tropical Africa is currently restricted to regions with semiarid to arid climates due to the fly-borne disease of trypanosomiasis. ${ }^{1}$ These regions are subjected to seasonal wet and dry periods averaging 6 months each with cyclical occurrences of drought. Seasonal variability in rainfall is an important consideration when evaluating producer's management practices with the existing forage/livestock system.

Most livestock production is based on communal grazing of native forages, and traditional management practices. Native forages are characterized by rapid-maturing perennial grasses which achieve their maximum quality quickly (Cassady 1973; Karue 1975). Availability and quality of forage for livestock production remain high for a short period of time under tropical conditions duc to a rapid rate of senescence and decay (Cassady 1973). By the middle of the dry season, the nutritive value of forage falls below the maintenance requirement for cattle, which places severe limitations on livestock productivity until 6 weeks after start of rains (Meyn 1970). Typically, feed is neither reserved nor stored except for commercial dairy herds.

The stress on cattle due to shortage and low quality of forage results in low productivity characterized by $50-70 \%$ calving rates, $25-35 \%$ death rate for calves before weaning, a slow rate of growth to mature size, and a low commercial offtake (Meyn 1970; Sullivan and Farris 1976). Documented low levels of technology adoption by traditional herdsmen combined with communal grazing result in inefficient use of range resources (Sullivan et al. 1978). The objective of the study was to illustrate the applicability of forage and herd simulation models to analyze an alternative forage/livestock system in Tropical Africa for improving forage utilization and nutrition of livestock and people.

Authors are, respectively assistant professor, Department of Agricultural Economics and Rural Sociology, Auburn University, formerly research assistant, Texas A\&M University when research was conducted; research assistant, professor, Department of Agricultural Economics, Texas A\&M University; research associate and professor. Department of Animal Science. Texas A\&M LIniversity. Helpful advice on validating forage model was given by J. Cassady, A.J. Dye, and R. Pederson; however, authors are solely responsible for views express. Texas Agricultural Experiment Station Technical Article No. 14535.

Manuscript received August 31, 1978.

'Tropical Africa is defined as the area $30^{\circ}$ north and south of the equator and includes large areas where annual rainfall is less than $800 \mathrm{~mm}$

\section{Transforming a Traditional Livestock System}

New institutional organizations are being proposed in these livestock regions to change traditional communal grazing systems to achieve more efficient range utilization and higher livestock productivity. Tanzania, a major producer of livestock in Tropical Africa, has embarked on a new institution, "villagization", which involves the resettlement in rural populations into planned communities. Legal jurisdiction of all resources within the community's boundary is delegated to a village management committee. The present communal grazing system, in time, could be developed into village range management programs under the new institution.

With "villagization" officially complete in most areas of Tanzania, the incidence of overgrazing in the villages has increased because of the continuation of the communal grazing system with increased cattle concentrations. Both animal and human nutrition are at a low level under the present system (Meyn 1970; Singh 1976). In Shinyanga Region, southwest of Lake Victoria which served as the study area, the cattle and human concentration per hectare for a representative village are high, with production and cultural characteristics being fairly homogeneous (Table 1) (Sullivan and Farris 1976). On the average, families in the area with livestock (cattle, goats, and sheep) are meeting 107 and $116 \%$ of minimum required caloric and protein intake for African conditions from their own production, while families with only goats and sheep or no livestock are not meeting minimum requirements from their own agricultural produce (Table 2) (Latham 1965; Singh 1976; Sullivan and

Table 1. Forage/livestock resources of a representative village in Shinyanga Region, Tanzania, 1975.

\begin{tabular}{|c|c|c|c|c|c|}
\hline & $\begin{array}{l}\text { Head/ } \\
\text { family }\end{array}$ & $\begin{array}{l}\text { A.U./ } \\
\text { family' }\end{array}$ & $\begin{array}{l}\text { Family/ } \\
\text { village }\end{array}$ & $\begin{array}{l}\text { A.U./ } \\
\text { village }\end{array}$ & Village \\
\hline Keeping cattle & 26.1 & 29.5 & 180 & 5310 & \\
\hline Keeping goats & 8.1 & 1.89 & 156 & 295 & \\
\hline Keeping sheep & 9.6 & 1.89 & 136 & 261 & \\
\hline Keeping no livestock & & & 207 & & \\
\hline lotal & & & 566 & 5866 & \\
\hline Total area (ha) & & & & & 13000 \\
\hline Cultivated area (ha) & & & & & 1200 \\
\hline Unproductive area & & & & & 500 \\
\hline $\begin{array}{l}\text { (ha) } \\
\text { Rough grazing (ha) }\end{array}$ & & & & & 11300 \\
\hline
\end{tabular}

'A.U. is animal units and equivalent to a mature dry cow of $250 \mathrm{~kg}$ Source: Sullivan and Farris (1976). 
Table 2. Annual per Capital consumption of calories and protein available from own production in a representative village in Shinyanga Region, Tanzania, 1975-76.

\begin{tabular}{|c|c|c|c|c|c|c|}
\hline & \multicolumn{2}{|c|}{$\begin{array}{l}\text { Families with } \\
\text { cattle, sheep, goats } \\
(\mathrm{n}=180)\end{array}$} & \multicolumn{2}{|c|}{$\begin{array}{c}\text { Families with } \\
\text { sheep and goats } \\
(\mathrm{n}=179)\end{array}$} & \multicolumn{2}{|c|}{$\begin{array}{l}\text { Families with/out } \\
\text { livestock } \\
(n=207)\end{array}$} \\
\hline & $\begin{array}{r}\text { Calories } \\
\text { (cal) }\end{array}$ & $\begin{array}{c}\text { Protein } \\
\text { (g) }\end{array}$ & $\begin{array}{c}\text { Calories } \\
\text { (cal) }\end{array}$ & $\begin{array}{l}\text { Protein } \\
\text { (g) }\end{array}$ & $\begin{array}{c}\text { Calories } \\
\text { (cal) }\end{array}$ & $\begin{array}{l}\text { Protein } \\
\text { (g) }\end{array}$ \\
\hline Nutritional requirement: & 716,860 & 14,837 & 716,860 & 14,837 & & 14,837 \\
\hline Consumption food crop & 686,573 & 10,974 & 686,473 & 10,974 & 686,573 & 10,974 \\
\hline$\%$ of requirement & .96 & .74 & .96 & .74 & .96 & .74 \\
\hline Consumption cow's milk: & 39,680 & 2,046 & - & - & - & - \\
\hline Total nutri. intake: & 726,253 & 13,020 & - & - & - & - \\
\hline$\%$ of requirement & 1.01 & .88 & - & - & - & - \\
\hline Consumption of beef; & 24,906 & 2,343 & - & - & - & - \\
\hline Total nutritional intake & 751,159 & 15,363 & - & - & - & - \\
\hline$\%$ of requirement & 1.05 & 1.04 & - & - & - & - \\
\hline Consumption of goat and sheep: & 14,900 & 1,700 & 14,900 & 1,700 & - & - \\
\hline Total intake of nutrition & 768,221 & 17,266 & 701,473 & 12,764 & 686,573 & 10,974 \\
\hline$\%$ of Requirement: & 1.07 & 1.16 & .98 & .85 & .96 & .74 \\
\hline
\end{tabular}

Source: Sullivan and Farris, 1976; and I.J. Sing, "Annex on Subsistence Requirements in Sukumaland," World Bank, September 2,. 1976.

Farris 1976). Averages conceal the skewed distribution in most villages where the majority of families have small cultivated plots and small herds of livestock and live below minimum nutritional levels (Singh 1976). The area is classified as a mixture of wooded grassland and open savannahs which Pratt, Greenway, and Gwynne have classified as being in Ecological Zone IV. The top soil is black and loamy, suitable for cotton production, and the predominant perennial grass is Themeda triandra, a major species throughout East Africa (Pratt et al. 1966). Average annual rainfall in Shinyanga Region has been $837 \mathrm{~mm}$ with an average of 71 rainy days (Table 3 ). The wet season is primarily from November through April.

The hypothesis to be tested is that the "villagization" program as an institution empowered to manage available resources can increase overall village welfare by improved herd and range management not feasible under the traditional communal grazing system. The village committee can allocate land for hay making near the village and require families which own cattle to cut and store hay when forage quality is highest for utilization by lactating cows during stress periods. The specific hypothesis examined was that such a system would produce positive net benefits measured in both nutritional and monetary terms.

\section{Methodology}

Personal field interviews of 127 livestock producers in 14 villages in Shinyanga Region in 1975 were used to construct a representative village. Available rough grazing for livestock was assumed to be a circular area with a radius of 4 miles due to the area's high human population density and the practice of corralling cattle in the village at night (Table 1).

A forage simulation model adapted from a forage-sheep production model in Australia was applied to the major perennial grass, Themeda triandra, in Shinyanga Region in Tanzania (Smith and Williams 1973). Daily rainfall, pan evaporation, and radiation were control variables affecting the growth, transformation, and senescence of standing biomass (Table 3). Standing forage biomass and the ratio of green grass to total forage was estimated from exponential equations for growth of green grass, transformation of green to dry grass, and decay of dry grass as influenced by available soil moisture and fertility. The model parameter, standing biomass, was validated with research results for a similar production environment in Ecological Zone IV in Kenya (Cassady 1973; Karue 1975). Simulation of forage production was adjusted to reflect range conditions with and without livestock grazing pressure. Hay production was simulated from natural range pasture, which was not subject to livestock grazing pressure.

A herd production simulation model for the "representative" village was adapted from a model designed by Sanders (1977). The general structure of this simulation model has been tested and validated for several production environments in the United States and tropical countries (Sanders 1977; ILCA 1978). The model's primary inputs are monthly crude protein and digestibility of forages (percent of dry matter), specified potential size for a dry mature cow with adequate nutrition (280 kg liveweight), and potential peak milk yield $(6.5 \mathrm{~kg} /$ day $)$ derived from field research in East Africa (Meyn 1970). The dominant indigenous breed is the Tanzanian shorthorn zebu. The herd simulation model, given these inputs, estimates total monthly dry matter consumption from which monthly carrying capacity, expressed as animal unit per hectare (A.U./ha), was derived by assuming that a standard animal unit $(250 \mathrm{~kg} \mathrm{cow})$ has the potential to consume $181 \mathrm{~kg}$ of dry matter per month. Variation betwen monthly carrying capacities, expresses the change in quality of forage. Monthly carrying capacity from the herd simulation model was used as an input into the forage model to determine utilization of the village's rangeland.

Table 3. Average/rainfall (mm/month), pan evaporation (PEV) (mm/ month), and radiation Langley/day by months for Shinyanga Region, Tanzania.

\begin{tabular}{lrrrr}
\hline & Rainfall & PEV & Radiation & $\begin{array}{c}\text { Rainy days per } \\
\text { month } \geq 2, \text {, }\end{array}$ \\
\hline January & & & & days \\
February & 123 & 171 & 509 & 10 \\
March & 121 & 153 & 481 & 11 \\
April & 151 & 174 & 479 & 12 \\
May & 138 & 167 & 483 & 11 \\
June & 42 & 177 & 509 & 5 \\
July & 3 & 199 & 514 & 1 \\
August & 1 & 257 & 523 & 0 \\
September & 1 & 257 & 523 & 0 \\
October & 6 & 270 & 529 & 1 \\
November & 27 & 267 & 528 & 3 \\
December & 145 & 204 & 492 & 6 \\
Average Annual & 837 & 176 & -482 & -11 \\
\hline
\end{tabular}

Source: East Africa Meteorological Department, 1975. 
Table 4. Comprison of traditional and improved management (hay supplementtion) systems for village herd ${ }^{1}$ in Shinyanga Region, Tanzania.

Traditional

Improved hay supplement

\begin{tabular}{|c|c|c|c|c|c|c|c|c|c|c|c|}
\hline Month & $\begin{array}{l}\text { D.M. } \\
\text { consumed } \\
(000 \mathrm{~kg})\end{array}$ & $\begin{array}{l}\text { Carrying } \\
\text { capacity } \\
\text { (A.U./ha) }\end{array}$ & $\begin{array}{c}\text { Total milk } \\
\text { yield } \\
(000 \mathrm{~kg})\end{array}$ & $\begin{array}{l}\text { Milk to } \\
\text { humans } \\
(000 \mathrm{~kg})\end{array}$ & $\begin{array}{l}\text { Avg. daily } \\
\text { output per } \\
\text { lactating cow } \\
(\mathrm{kg})\end{array}$ & $\begin{array}{l}\text { D.M. }^{3} \\
\text { consumed } \\
(000 \mathrm{~kg})\end{array}$ & $\begin{array}{c}\text { Hay } \\
\text { consumed } \\
(000 \mathrm{~kg})\end{array}$ & $\begin{array}{l}\text { Carrying } \\
\text { capacity } \\
\text { (A.U./ha) }\end{array}$ & $\begin{array}{c}\text { Total milk } \\
\text { yield } \\
(000 \mathrm{~kg})\end{array}$ & $\begin{array}{l}\text { Milk to } \\
\text { humans } \\
(000 \mathrm{~kg})\end{array}$ & $\begin{array}{l}\text { Avg. daily } \\
\text { output per } \\
\text { lactating } \\
\text { cow (kg) }\end{array}$ \\
\hline Jan. & 844 & .41 & 86 & 19 & 3.23 & 873 & - & .43 & 88 & 21 & 3.22 \\
\hline Feb. & 838 & .41 & 88 & 17 & 3.10 & 863 & - & .42 & 90 & 20 & 3.10 \\
\hline Mar. & 851 & .42 & 85 & 14 & 2.92 & 877 & - & .43 & 87 & 16 & 2.93 \\
\hline Apr. & 828 & .41 & 74 & 9 & 2.56 & 858 & - & .42 & 78 & 13 & 2.61 \\
\hline May & 634 & .31 & 60 & 6 & 2.04 & 622 & - & .32 & 63 & 8 & 2.09 \\
\hline June & 592 & .29 & 39 & 3 & 1.35 & 626 & - & .31 & 43 & 7 & 1.44 \\
\hline July & 580 & .28 & 18 & 2 & .64 & 602 & 18 & .30 & 21 & 6 & .74 \\
\hline Aug. & 515 & .25 & 10 & 2 & .38 & 540 & 15 & .26 & 15 & 7 & .56 \\
\hline Sept. & 445 & .22 & 10 & 2 & .45 & 460 & 16 & .22 & 16 & 8 & .76 \\
\hline Oct. & 525 & .26 & 18 & 4 & .77 & 531 & 22 & .26 & 25 & 12 & 1.05 \\
\hline Nov. & 688 & .34 & 36 & 8 & 1.50 & 677 & 37 & .33 & 43 & 16 & 1.75 \\
\hline Dec. & 856 & .42 & 76 & 14 & 3.11 & 888 & - & .44 & 80 & 17 & 3.13 \\
\hline Annual & 8,197 & & 600 & 102 & 1.84 & 8,565 & 108 & & 648 & 150 & .95 \\
\hline
\end{tabular}

Village herd consists of 5,866 animal units where A.U. $=250 \mathrm{~kg}$ dry cow.

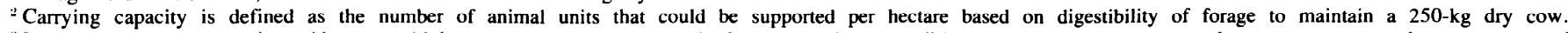

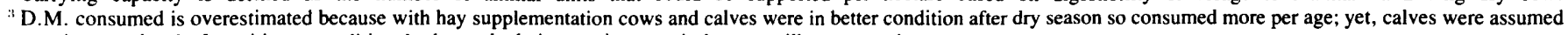
to retain same level of nutrition as traditional when calculating net increase in human milk consumption.

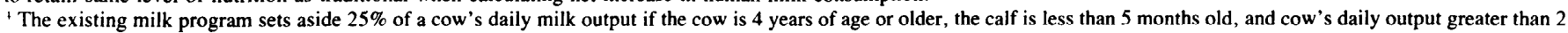

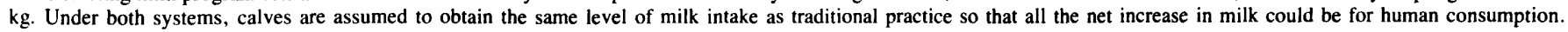

Monthly total milk yield for the traditional management system and the improved system of storing and feeding hay was estimated from the herd model. The existing milk program sets aside a percentage of the daily milk output for human consumption (See Table 4, Footnote 4). Monthly intake of hay during the period July through November, by lactating cows over 4 years old with calves less than 5 months, was estimated by the model. Average quality of hay was assumed to be $8 \%$ crude protein (CP) and $53 \%$ total digestible nutrients (TDN) (French, 1956). The value of a haymaking enterprise was evaluated by the estimated net benefit to human nutrition solely from increased milk yields. A cost/benefit analysis of the milk sold to other members in the village was used to estimate the profitability of the enterprise.

\section{Results}

Results of the forage/livestock models are reported for the fifth year of simulation. Forage production during simulation of the fifth year beginning in November, start of the rainy season, are reported without livestock grazing (Figures la, $1 \mathrm{~b}, 1 \mathrm{c})$. Total standing biomass $(\mathrm{HW})$ reached $4,000 / \mathrm{kg} /$ ha (dry matter) after approximately 190 days from initial growth. The total weight of green grass $(\mathrm{GW})$ increased at an increasing rate for the first 90 days of the wet season. After this period, growth is less rapid due partly to maturity of plant and also leaching of nutrients from soil. All standing green grass (GW) disappears 50-60 days after end of rains in late April (Fig. la) (Cassady 1973).

Livestock have a limited period of time to graze high quality forage. In Figure $1 \mathrm{~b}$, the predicted growth, drying, and decay rates for Themeda triandra are presented. Growth rates per day peaked at $100 \mathrm{~kg}$, dropping to between 40 to $60 \mathrm{~kg}$ after first 90 days. During the wet season, senescence and loss through decay of forage occurs quickly, leaving grass for hay in situ with little value. The percentage of green grass (GW) to total standing biomass (HW) (PERGW) in Figure if can be correlated with CP and TDN in Figure $1 \mathrm{c}$ to show that nutrient value of forage peaks quickly loses its quality as the standing forage matures. By the latter part of the dry season TDN was below $45 \%$ and $C P$ dropped to $4 \%$ (dotted line in Figure $1 \mathrm{c}$ is required level for cattle maintenance, $6 \% \mathrm{CP}$ ).

The forage system with current communal grazing is estimated in Figures 1d, If. Monthly carrying capacity expressed as animal units per hectare was derived from the monthly total dry matter consumption for the representative village herd from the herd simulation model for each respective management system (Table 4). Daily intake of forage per animal unit per hectare varies according to total digestible nutrients (TDN) of the forage, a relationship calculated by Conrad, Hibbs and Pratt (1966). For the months of November through April, daily intake (kg/A.U./ha) of green grass (DEFG) is above $2 \mathrm{~kg}$ when PERGW is also high (Fig. If). Forage intake falls below $2 \mathrm{~kg}$ per day (DEFD) when TDN of forage is low (Fig. 1c) and grass is dry with PERGW declining. With livestock grazing and forage intake (kg/A.U./ ha) varying due to TDN, maximum dry matter yield was estimated at $3,200 \mathrm{~kg} / \mathrm{ha}$ (Fig. 1d). Standing forage accumulates when quality is high because uncontrolled communal grazing is unable to efficiently utilize forage when it is in surplus. Consequently, valuable forage is lost due to rapid drying and decay of grasses (Fig. 1b).

Baseline monthly milk production for a representative village without hay supplementation for the fifth year of computer simulation is shown in Table 4. During the dry season average daily milk yields declined, indicating less milk for home consumption. This period places greatest stress on calves with a larger percentage dying during this time (Sullivan and Farris 1976). With hay supplementation for lactating cows, annual milk production for the representative village herd increased $8 \%$, approximately $48,000 \mathrm{~kg}$ (Table 5). If the level of calf nutrition is assumed the same in the improved and the traditional system, then human consumption of milk increased from 63 litres to 91 litres/person/cattle-owning-family. With milk consumption only, calorie and protein intake/person/cattle-owningfamily increased by 18,750 calories and 967 grams of 

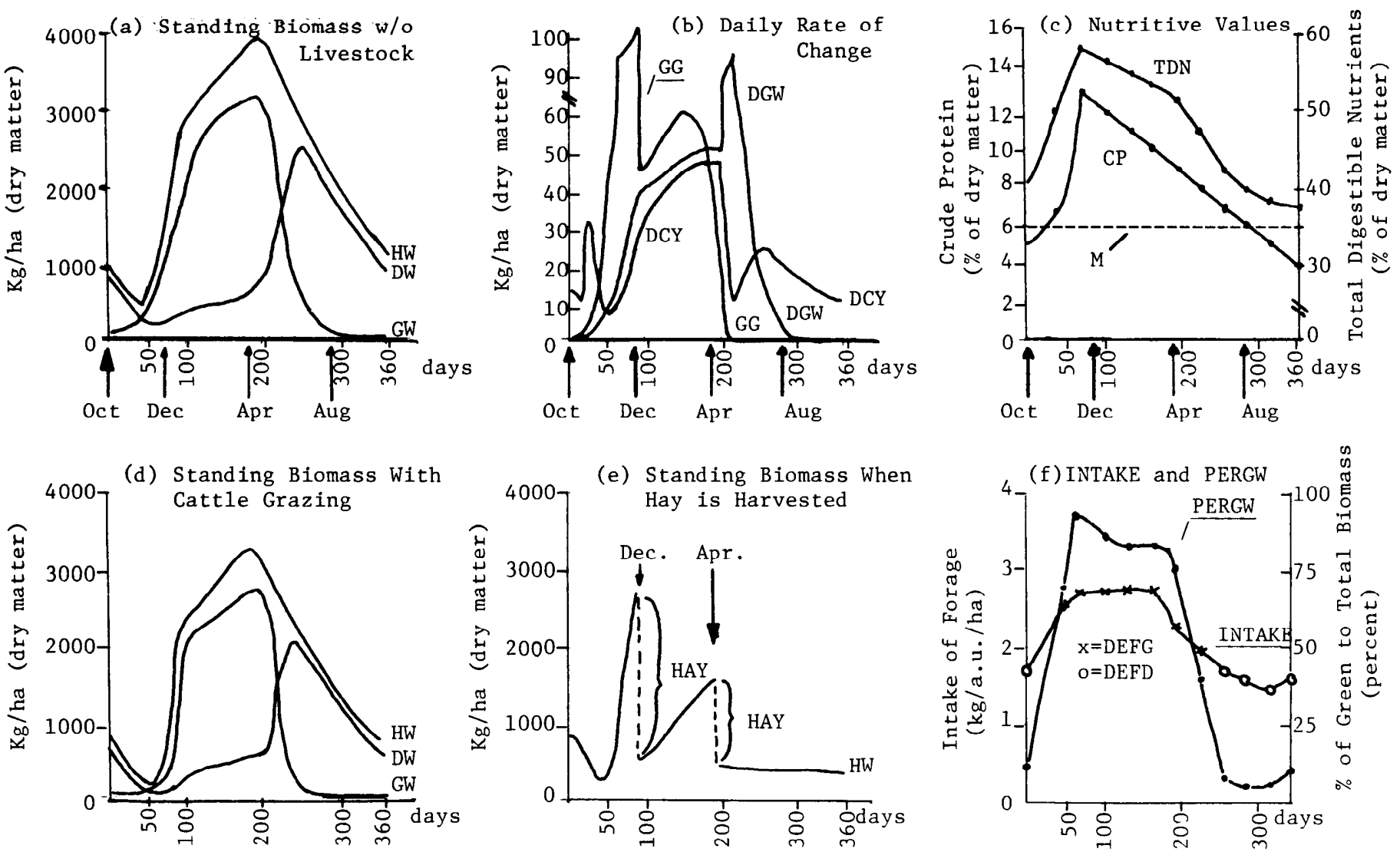

Fig. 1. Forage Simulations for Tropical Forage, Themeda triandra. (a) Standing Biomass Without Livestock Grazing with Total Weight ( $\mathrm{HW}$, Weight of Dry Grass (DW) and Weight of Green Grass (GW). (b) Daily Rate of Change in Growth of Green Grass $(G G)$, Green Grass Converted to Dry Grass (DGW), and Decay of Dry Grass (DCY). (c) The Change in Total Digestible Nutrients (TDN) (\% of Dry Matter), Crude Protein (CP) (\% of Dry Matter) of Forage and the Maintenance Level $(M)$ of

protein. If the additional milk were sold to families without cattle, then calorie intake per person would increase 13,722 calories and 708 grams of protein (Table 5). This results in $99 \%$ of the minimum calorie requirement and increases

Table 5. Gross benefits from increased milk production with hay supplementation program for representative village herd in Shinyanga Region, Tanzania.

\begin{tabular}{|c|c|c|c|c|}
\hline \multirow[b]{2}{*}{ Month } & \multirow{2}{*}{$\begin{array}{l}\text { Changes in } \\
\text { milk } \\
\text { production } \\
(000 \mathrm{~kg})\end{array}$} & \multirow{2}{*}{$\begin{array}{l}\text { Value of } \\
\text { milk } \\
\text { (000 Tsh.) }\end{array}$} & \multicolumn{2}{|c|}{$\begin{array}{l}\text { Increase in per capita nutrient } \\
\text { intake }^{1}\end{array}$} \\
\hline & & & $\begin{array}{c}\text { Calories } \\
\text { (cal) }\end{array}$ & $\begin{array}{l}\text { Protein } \\
\text { (g) }\end{array}$ \\
\hline Jan & 2.6 & 5.2 & 737 & 38 \\
\hline Feb. & 2.2 & 4.4 & 625 & 32 \\
\hline Mar. & 2.3 & 4.6 & 653 & 134 \\
\hline Apr. & 3.7 & 7.4 & 1049 & 54 \\
\hline May & 2.6 & 5.2 & 738 & 38 \\
\hline June & 3.3 & 6.6 & 935 & 48 \\
\hline July & 3.1 & 6.2 & 879 & 45 \\
\hline Aug. & 5.0 & 10.0 & 1417 & 73 \\
\hline Sept. & 5.9 & 11.8 & 1672 & 86 \\
\hline Oct. & 7.2 & 14.6 & 2041 & 105 \\
\hline Nov. & 7.3 & 14.6 & 2069 & 107 \\
\hline Dec. & 3.2 & 6.4 & 907 & 48 \\
\hline Annual & 48.4 & 96.0 & 13722 & 708 \\
\hline
\end{tabular}

1 Per capita nutrient consumption is for families in the representative village without cattle.
Crude Protein for Cattle. (d) Standing Biomass with Cattle Grazing for an Estimated Monthly Village Stocking Rate. (e) Standing Biomass When Hay is Harvested Without Livestock Grazing. (f) Daily Forage Intake per Animal Unit per Hectare (INTAKE) of Green Grass (DEFG) and Dry Grass (DEFD) and the Ratio of Green Weight to Total Biomass (PERGW) (\% of $G W$ to $H W$ ).

protein intake from 74 to $81 \%$ of necessary requirement. Individuals, which before were without this source of nutrition, now had approximately one-third the per capita milk consumption of individuals with cattle (Table 2). On an individual lactating cow basis, the improved management system increased daily output by $6 \%$ (Table 4 ); but more importantly a larger proportion of the increase in milk output comes in four critical months, August through November, during the dry season (Table 5).

Amount of hay required from July to November to feed lactating cows 4 years and older with calves less than 5 months was estimated from the herd model to be 108,000 $\mathrm{kg}$ (Table 4). With two harvests per hectare per year, the area required to meet this hay consumption level was 34 hectares with an average yield of $1,600 \mathrm{~kg} / \mathrm{ha}$ (dry matter) per harvest (Figure 1e). The hay enterprise was controlled by cutting hay when the ratio of green grass to total biomass (PERGW) was a maximum (Figure 1f). The first cut occurred 60 to 80 days after initial growth and the second 3 months later at end of rains (Figure 1e). The first harvest coincides with end of short rains when there is less demand for hired labor since fields have been planted (Singh 1976).

Shinyanga Region is primarily a cotton production zone with tractors commonly found in villages; therefore, cutting and transporting hay could be done without great demands on traditional agricultural systems. A cost of Tsh. 75 per hour for the use of the village-owned tractor was charged to 
the hay enterprise. ${ }^{2}$ Cutting, raking, and hauling loose hay was estimated to require five tractor-hours per hectare. Labor for stacking and storing loose hay was estimated at 21 man-hours per metric ton at a cost of Tsh. 1.75 per hour (Ministry of Agriculture, Tanzania, 1974). Annual ownership and maintenance costs of mower, rake, and storage facilities is Tsh. 8,000 per year giving a total cost of Tsh. 24,833 or Tsh. 138 per family with cattle. The value of milk in the village was assumed to be Tsh. $2 / \mathrm{kg}$ so that total revenue to cattle owners was Tsh. 96,000. Net income from sale of milk was Tsh. 395 per family owning cattle, which was $56 \%$ of estimated current per capital gross domestic production in Shinyanga Region (World Bank 1974).

In further research, a hay supplementation program was found to create additional benefits for the village livestock herd (Sullivan 1979). General performance of a village herd increased with lower calf mortality rates and higher weaning weights. The village herd increased in numbers and sustained periods of simulated dry periods in better physical condition.

\section{Conclusion}

Forage and herd simulation models were used to demonstrate methodology for evaluating an alternative forage/livestock system in Tropical Africa. The Tanzanian illustration is one in which traditional agricultural and livestock systems result in low human nutrition. A system approach examining biological inputs (forage) and livestock outputs (milk) expressed in human nutritional intake was the method used to evaluate alternative systems.

The results show a hay making enterprise would substantially increase utilization of forage, otherwise lost to senescence and decay. Hay making could be feasible economically when operated as a village enterprise; whereas, the activity is unlikely to be adopted by one individual because of communal grazing of the available rangeland. The authors realize the technical difficulty of making quality hay in a tropical environment and that the cultural aspects must be critically examined before a hay enterprise could be

${ }^{2}$ Current exchange rate in Tsh. 8.50 equals U.S. $\$ 1.00$. recommended for implementation. The hypothesis that hay production produces a net benefit to village welfare, however, can be accepted tentatively, pending actual trials in African villages.

\section{Literature Cited}

Cassady, John, 1973. The effect of rainfall, soil moisture and harvesting intensity on grass production on two rangcland sites in Kenya. East African Agr. and For. J. 39:26-36.

Conrad, H.R., J.W. Hibbs, and A.D. Pratt. 1966. Regulation of feed intake in dairy cows. II. Association between digestible dry matter intake and cellulose digestibility in cows fed increasing levels of grain concentrate. J. of Dairy Sci. 49:1038-1042.

East African Meteorological Department. 1975. Climatological Statistics for East Africa. East African Meteorol. Service, Nairobi: 100 p.

French, M.H. 1956. The nutritive value of East African hay. Empire J. of Exp. Agr. 24:100-110.

International Livestock Center for Africa (ILCA). 1978. Mathematical modelling of livestock production systems: application of Texas A\&M University beef cattle production model to Botswana. ILCA. System Study No. 1, Addis Ababa. 102 p.

Karue, C.N. 1975. The nutritive value of herbage in semi-arid lands of East Africa: II Seasonal influence on the nutritive value of Themeda triandra. East African Agr. and For. J. 40:372-387.

Latham, M. 1965. Human Nutrition in Tropical Africa. FAO, Rome.

Ministry of Agriculture, Tanzania. 1974. Phase I Dairy Development and Animal Health Project. Government Printing Office, Dar es Salaam. 65 p.

Meyn, Klaus. 1970. Beef Production in East Africa. Ifo Institute fur Wirshaftforschung, Munich. 227 p.

Pratt, D.J., P.J. Greenway, and M.D. Gwynne. 1966. A classification of East Africa rangeland. J. of Applied Ecol. 3: 369-382.

Sanders, J.0. 1977. Application of a beef cattle production model to the evaluation of genetic selection criteria. Unpublished doctoral dissertation, Texas A\&M University. 120 p.

Singh, I.J. 1976. Annex on Subsistence Requirement in Sukumaland, Tanzania. World Bank Memorandum, Washington D.C. 20 p.

Smith, Richard, and William Williams. 1973. Model Development for a Deferred-Grazing System. J. of Range Manage. 26:454-460.

Sullivan, G.M., and D.E. Farris. 1976. Survey of traditional livestock industry. Tanzania Livestock-Meat Subsector, Texas A\&M University, Vol. 2. 147 p.

Sullivan, G.M., D.E. Farris, M. Yetley, and J. Njukia. 1978. Socioeconomic analysis of technology adoption in an African livestock industry. Q. J. Intern. Agr. 17:150-160.

Sullivan, G.M. 1979. Economics of improved management for transforming the forage/livestock system in Tanzania-a simulation model. Unpublished Ph.D. dissertation Texas A\&M Univ. 222 p.

World Bank. 1974. Tanzania Agricultural and Rural Development Sector Study. Washington, D.C.

CHANGE OF ADDRESS notices should be sent to the Managing Editor, 2760 West Fifth Ave., Denver, Colo. 80204, no later than the first day of the month of issue. Copies lost due to change of address cannot be replaced unless adequate notice is given. To assure uninterrupted service, provide your local postmaster with a Change of Address Order (POD Form 3575) indicating thereon to guarantee forwarding postage for second-class mail. 